\title{
Clinical Implications of Augmenter of Liver Regeneration in Cancer: A Systematic Review
}

\author{
KEVIN H. NGUYEN, AUSTIN H. NGUYEN and DEEPA V. DABIR \\ Department of Biology, Loyola Marymount University, Los Angeles, CA, U.S.A.
}

\begin{abstract}
Background/Aim: Hepatocellular carcinoma is a substantial healthcare burden with high prevalence and poor prognosis. As such, efforts are continually made to uncover molecules relevant in cancer biology, that are exploitable as targets for therapy. The mitochondrion is the powerhouse of the cell and exhibits altered functionality in the malignant state, including aberrant regulation of apoptosis and cellular respiration. Augmenter of liver regeneration (ALR) is a multifunctional mitochondrial protein that demonstrates antioxidative and anti-apoptotic properties and plays a key role in liver regeneration. Materials and Methods: The present study systematically reviews the available literature on the role of ALR in cancer. Results: Systematic search of PubMed resulted in 12 studies discussing ALR in multiple types of cancer. More specifically, ALR appears to be up-regulated in malignant cells and tissues. Furthermore, treatment of cells with exogenous ALR shows an anti-apoptotic effect while silencing or inhibiting ALR decreases cell and tumor survival. Conclusion: ALR clearly plays a role in cancer biology and demonstrates potential as a therapeutic target.
\end{abstract}

Hepatocellular carcinoma (HCC) is a common oncologic condition with a poor prognosis that poses as a global burden on medical care (1). Between 2002 and 2012 the mortality rate of $\mathrm{HCC}$ rose by $34.8 \%$ in the United States and liver cancer, with HCC estimated as 70 to $90 \%$ of cases, was considered to be the second leading cause of cancer-related deaths among males on a global scale in 2012 (2, 3). Considering the metabolic aspect of several known risk

This article is freely accessible online.

Correspondence to: Dr. Deepa V. Dabir, 1 LMU Drive, Department of Biology, Loyola Marymount University, Los Angeles, CA 90045, USA. Tel: +1 3103384200, e-mail: ddabir@1mu.edu

Key Words: Augmenter of liver regeneration, ALR, malignancy, review. factors for HCC, such as obesity, diabetes, and non-alcoholic fatty liver disease, a common underlying feature of mitochondrial dysfunction is of growing interest in molecular oncology. The regulation of specific mitochondrial proteins is of particular interest, as these proteins demonstrate potential as therapeutic targets for HCC (4).

Augmenter of liver regeneration (ALR) is one particular protein of interest that localizes in the intermembrane space of the mitochondria of humans and has a prokaryotic homolog, Erv1, sharing 42\% identical amino acid residues. ALR/Erv1 has been known to contribute to mitochondrial biogenesis and function as a sulfhydryl oxidase in mitochondrial disulfide relay systems (5). It functions to oxidize the import receptor Mia40, both of which conjunctively import small translocase inner membrane (Tim) proteins through an oxidative-folding pathway (6). In turn, cytochrome $c$ (cyt $c$ ), which constitutes an important member of the electron transport chain, oxidizes ALR through locomotion of electrons via FAD, thus connecting this redox regulated import pathway to electron transport $(5,7)$. During specific unfavorable conditions, cells must reprogram to undergo apoptosis during which cyt $c$ activates a series of activated-caspase pathways that lead to cell suicide (8). It is a trademark of cancer cells to down-regulate apoptotic mechanisms and alter mitochondrial respiratory function, resulting in uncontrolled growth and eventual metastasis of cancerous cells. ALR manifests anti-oxidative and anti-apoptotic properties and is known to support liver regeneration in cases of hepatic injury (9). Considering these properties, early investigations have suggested a role for ALR in cancer (particularly hepatocellular) pathogenesis, growth and progression. In this study, we systematically review the literature discussing ALR in cancer. Clinical implications including oncogenesis and targeted therapy are explored.

\section{Materials and Methods}

A systematic review was performed using the National Library of Medicine PubMed database. The search was performed using the following key terms: cancer and augmenter of liver regeneration, growth factor erv1-like, GFER, or hepatic regenerative stimulation 
Table I. Summary of study details investigating ALR in cancer.

\begin{tabular}{|c|c|c|c|c|c|c|c|}
\hline Study & $\begin{array}{l}\text { Cancer } \\
\text { type }\end{array}$ & $\begin{array}{c}\mathrm{N} \\
\text { (total) }\end{array}$ & $\begin{array}{c}\mathrm{N} \\
\text { (cancer) }\end{array}$ & $\begin{array}{c}\text { Gender } \\
\mathrm{M}: \mathrm{F}\end{array}$ & $\begin{array}{l}\text { rean age } \\
\text { (range) }\end{array}$ & Tissue & Assays \\
\hline Cao et al., 2009 & $\mathrm{HCC}$ & 11 & 11 & $9: 2$ & $54.1(37-66)$ & Frozen & $\begin{array}{l}\text { qPCR, H2DCF-DA, } \\
\text { flow cytometry }\end{array}$ \\
\hline Dayoub et al., 2011 & $\mathrm{HCC}$ & 64 & 53 & - & - & Cell line HepG2, FFPE & $\begin{array}{c}\text { IHC, migration/invasion assays, } \\
\text { RT-PCR, WB }\end{array}$ \\
\hline Denk et al., 2010 & $\mathrm{HCC}$ & - & - & - & - & Cell line HuH-7 & $\begin{array}{l}\mathrm{WB}, \mathrm{PCR} \text {, formazan formation } \\
\text { cell viability assay }\end{array}$ \\
\hline Gandhi et al., 2015 & $\mathrm{HCC}$ & - & - & - & - & FFPE, mice & $\begin{array}{l}\text { IHC, WB, RT-PCR, transmission } \\
\text { electron microscopy }\end{array}$ \\
\hline Gatzidou et al., 2015 & $\mathrm{CRC}$ & 42 & 23 & $11: 12$ & 68.8 & Cell lines, frozen tissue & qPCR \\
\hline Ilowski et al., 2011 & Various & - & - & - & - & Cell lines & WB, FACS \\
\hline Polimeno et al., 2009 & Neuroblastoma & - & - & - & - & Cell line SH-SY5Y & Cell viability, flow cytometry, ICC, WB \\
\hline Polimeno et al., 2012 & Glioma & - & - & - & - & Cell line T98G & $\begin{array}{l}\text { WB, ICC, flow cytometry, } \\
\text { electron microscopy }\end{array}$ \\
\hline Shen et al., 2013 & $\mathrm{~T}$ cell leukemia & - & - & - & - & Cell line Jurkat & Cell viability, flow cytometry, WB \\
\hline Tang et al., 2009 & $\mathrm{HCC}$ & - & - & - & - & Cell line HepG2, mice & ICC, RT-PCR, mouse tumor model \\
\hline Thasler et al., 2005 & $\mathrm{HCC}$ & 71 & 9 & $5: 4$ & 66.2 & FFPE, cell line HepG2 & IHC, RT-PCR, WB \\
\hline Yu et al., 2010 & $\mathrm{HCC}$ & $\begin{array}{l}\text { Serum: } 72 \\
\text { Tissue: } 58\end{array}$ & $\begin{array}{l}\text { Serum: } 20 \\
\text { Tissue: } 6\end{array}$ & - & - & Serum, FFPE & ELISA, RT-PCR, IHC \\
\hline
\end{tabular}

ALR: Augmenter of liver regeneration; CRC: colorectal cancer; FACS: fluorescence-activated cell sorting; FFPE: formalin-fixed paraffin embedded; HCC: hepatocellular carcinoma; ICC: immunocytochemistry; IHC: immunohistochemistry; PCR: polymerase chain reaction; RT-PCR: reversetranscription polymerase chain reaction; WB: western blot.

substance. Articles were screened by titles and abstracts for possible relevance. Subsequently, full-text articles were retrieved for final inclusion decision. Inclusion criteria were: discussion of ALR in cancer, written in English, use of human subjects/samples. Conference abstracts and literature reviews were excluded from the present study.

\section{Results}

Systematic search of PubMed initially returned 41 articles, shown in Figure 1. Screening by titles and abstracts eliminated 28 articles. Full-text review eliminated one article that was an editorial and did not contain original data. Ultimately, 12 articles were included in the present review (10-21). Study characteristics are summarized in Table I.

Hepatocellular carcinoma. Results of studies investigating ALR in cancer are summarized in Table II. The majority of included studies observe ALR to be upregulated in malignant cells. In frozen and paraffin-embedded HCC tissue, ALR expression is consistently altered when compared to normal para-tumoral tissue and/or healthy controls $(10,11,13,20$, 21). The majority of studies suggest ALR mRNA and protein levels to be higher in HCC tissue relative to normal tissue. In HCC tissue, ALR typically demonstrates cytoplasmic localization with a granular quality on immunostaining (20). Dayoub and colleagues, however, observe the short ALR isoform of $15 \mathrm{kDa}$ to be expressed at lower levels in HCC overall, compared to normal liver tissue (11). Furthermore,

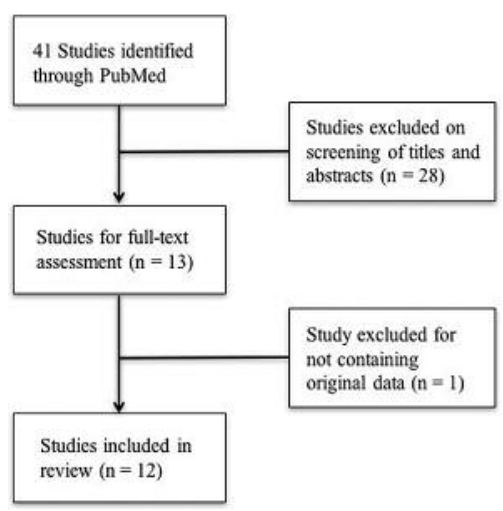

Figure 1. Systematic review of PubMed for articles discussing the clinical value of ALR in cancer. Initial search returned 41 articles. Screening by titles, abstracts, and full texts resulted in 12 articles remaining for final inclusion in this review.

this study found ALR expression to be inversely correlated with tumor grade and histologic angioinvasion. No other studies specified the isoform of ALR investigated. Additionally, one study demonstrated serum ALR levels to be unchanged in patients with HCC (21).

The bulk of studies investigated the role of ALR in cancer biology using HCC cell lines. In vitro, ALR is consistently associated with a protective effect on cancer cell survival and 
Table II. Summary of clinical implications of ALR in cancer.

\begin{tabular}{|c|c|c|}
\hline Study & Cancer & Findings \\
\hline Cao et al., 2009 & $\mathrm{HCC}$ & $\begin{array}{l}\text { - ALR is up-regulated by greater than twofold in } 81.9 \% \text { of HCC specimens, } \\
\text { compared to adjacent noncancerous tissue } \\
\text { - Overexpression of ALR in HCC cell lines was associated with increased survival after irradiation, } \\
\text { attenuates post-irradiation mitochondrial dysfunction, and inhibits mitochondria-dependent apoptosis } \\
\text { - ALR silencing inhibited growth and survival of HCC lines, but had minimal effect } \\
\text { on normal hepatocyte cells }\end{array}$ \\
\hline $\begin{array}{l}\text { Dayoub et al., } \\
2011\end{array}$ & $\mathrm{HCC}$ & $\begin{array}{l}\text { - The short ALR isoform of } 15 \mathrm{kDa} \text { is expressed less in HCC cells, compared to normal liver tissue } \\
\text { - Reexpression of the } 15 \mathrm{kDa} \text { ALR isoform in HCC cells reduces migration and invasiveness and } \\
\text { attenuates tumorigenicity } \\
\text { - ALR expression in HCC tissue inversely correlates with tumor grade and rate of histological angioinvasion }\end{array}$ \\
\hline Denk et al., 2010 & $\mathrm{HCC}$ & $\begin{array}{l}\text { - Transfection of HCC cells with ALR does not decrease apoptosis after treatment with } \\
\text { glycochenodeoxycholic acid }\end{array}$ \\
\hline $\begin{array}{l}\text { Gandhi et al., } \\
2015\end{array}$ & $\mathrm{HCC}$ & $\begin{array}{l}\text { - Liver-specific ALR knock-out mice demonstrated decreased mitochondrial respiratory function, } \\
\text { defective mitochondrial fatty acid transport and ATP synthesis } \\
\text { - They also demonstrated increased oxidative stress, steatosis, hepatocyte apoptosis, mitochondrial } \\
\text { structural abnormalities } \\
\text { - HCC developed in nearly } 60 \% \text { of liver-specific ALR knock-out mice by } 1 \text { year } \\
\text { - ALR levels were lower in patients with advanced alcoholic liver disease and nonalcoholic } \\
\text { steatohepatitis compared to controls }\end{array}$ \\
\hline $\begin{array}{l}\text { Gatzidou et al., } \\
2015\end{array}$ & CRC & $\begin{array}{l}\text { - ALR was expressed at higher levels in CRC cell lines compared to controls } \\
\text { - ALR expression was significantly increased in well/moderately differentiated tumors compared to } \\
\text { poorly differentiated tumors } \\
\text { - ALR tended to be higher in CRC tissue compared to matched non-neoplastic tissue }\end{array}$ \\
\hline $\begin{array}{l}\text { Ilowski et al., } \\
2011\end{array}$ & Various & $\begin{array}{l}\text { - HCC cells cultured in rhALR significantly decreased apoptosis induced by ethanol, TRAIL, anti-Apo, } \\
\text { TGF- } \beta \text {, and actinomycin D } \\
\text { - rhALR treatment did not reduce apoptosis in bronchial, colonic, gastric, and pancreatic cell lines }\end{array}$ \\
\hline $\begin{array}{l}\text { Polimeno et al., } \\
2009\end{array}$ & Neuroblastoma & - Neuroblastoma cells cultured with ALR exhibited improved survival in $\mathrm{H}_{2} \mathrm{O}_{2}$-induced apoptosis \\
\hline $\begin{array}{l}\text { Polimeno et al., } \\
2012\end{array}$ & Glioma & $\begin{array}{l}\text { - Glioma cells treated with rhALR dose-dependently decreased ROS levels in } \mathrm{H}_{2} \mathrm{O}_{2} \text {-treated cells } \\
\text { - Silencing of ALR-endcoding mRNA decreased clusterin and bcl-2 levels and increased } \\
\text { apoptosis and apoptotic markers caspase-9, activated caspase-3, ROS, and mitochondrial degeneration }\end{array}$ \\
\hline Shen et al., 2013 & $\begin{array}{c}\text { T cell } \\
\text { leukemia }\end{array}$ & $\begin{array}{l}\text { - Leukemic T cells show upregulation of ALR compared to normal T lymphocyte controls } \\
\text { - Culture of leukemic T cells with ALR reduces sensitivity to vincristine treatment } \\
\text { but does not effect proliferation }\end{array}$ \\
\hline Tang et al., 2009 & $\mathrm{HCC}$ & $\begin{array}{l}\text { - Silencing of ALR inhibited growth of HCC cells in vitro } \\
\text { - Silencing of ALR and treatment of anti-ALR monoclonal antibodies both inhibited } \\
\text { xenografted HCC tumors in nude mice }\end{array}$ \\
\hline Thasler et al., 2005 & $\mathrm{HCC}$ & $\begin{array}{l}\text { - HCC tissue demonstrated intense cytoplasmic granular immunostaining for ALR } \\
\text { - ALR mRNA expression in HCC tissue was significantly higher compared with normal liver tissue samples }\end{array}$ \\
\hline Yu et al., 2010 & $\mathrm{HCC}$ & $\begin{array}{l}\text { - Serum ALR levels did not differ among patients with HCC, chronic hepatitis B, and healthy controls } \\
\text { - ALR mRNA and protein levels were significantly higher in HCC liver tissues compared to healthy controls }\end{array}$ \\
\hline
\end{tabular}

ALR: Augmenter of liver regeneration; CRC: colorectal cancer; HCC: hepatocellular carcinoma; rhALR: recombinant human ALR; ROS: reactive oxygen species; TGF- $\beta$ : transforming growth factor beta; TRAIL: tumor necrosis factor related apoptosis-inducing ligand.

apoptosis. Cao et al. observed overexpression of ALR in HCC cells to have a protective effect against radiationinduced mitochondrial dysfunction and subsequent apoptosis (10). Additionally, treatment of HCC cells with ALR has a protective effect against apoptosis induced by ethanol, TRAIL, anti-Apo, TGF- $\beta$, and actinomycin D (15).

Silencing of ALR consistently demonstrated an antitumoral effect in HCC. Upon ALR silencing, overall growth and survival of HCC cells was inhibited, while a minimal effect was noted in normal hepatocyte cells $(10,19)$. In a murine HCC xenograft model, silencing of ALR and treatment with anti-ALR monoclonal antibodies both similarly inhibited tumor growth (19). Only one study reported that lowered ALR expression has been linked to HCC oncogenesis. In this study, mice with a liver-specific ALR knock-out were observed to have increased hepatosteatosis, hepatocyte apoptosis, and elevated HCC incidence of $60 \%$ at one year (13). 
Other cancers. Five studies discussed cancers other than HCC $(14,15,16,17,18)$. Gatzidou and colleagues observed elevated ALR levels in colorectal cancer (CRC) tissue and cell lines when compared to matched non-neoplastic tissue or controls, respectively (14). Similar to HCC, ALR expression in malignant tissue was inversely correlated with tumor grade. Namely, ALR was elevated in well to moderately differentiated tumors when compared to poorly differentiated ones. In another study, in vitro treatment with ALR does not appear to reduce apoptosis in bronchial, colonic, gastric, and pancreatic malignant cell lines (15). In T cell leukemia, cultured cells were observed to upregulate ALR compared to normal primary T lymphocytes (18). Furthermore, treatment with ALR reduces leukemic $\mathrm{T}$ cell sensitivity to vincristine.

ALR is of interest in neuronal tissue as well. Both neuroblastoma and glioma cells cultured with ALR exhibit a dose-dependent improvement in survival in $\mathrm{H}_{2} \mathrm{O}_{2}$-induced apoptosis $(16,17)$. Furthermore, silencing of ALR in glioma cells induces a pro-apoptotic state with increased reactive oxygen species generation and mitochondrial degeneration.

\section{Discussion}

Expression of ALR as assessed by varied qualitative and quantitative assays is clearly altered in malignancy. In light of the multifunctional nature of mitochondria, ALR likely plays a central role in cancer biology, in apoptotic regulation and cell respiration. In HCC tissues, ALR was consistently increased compared to healthy controls with the exception of one study which specifically investigated the $15 \mathrm{kDa}$ isoform. Via alternative splicing, ALR may be found as a 21/23-kDa isoform predominantly in the mitochondrial inter membrane space or as a $15-\mathrm{kDa}$ isoform at extracellular, nuclear, and cytoplasmic localizations (11). This likely accounts for the inconsistencies in ALR levels found across the included studies. In HCC, the malignant state may be associated with an altered expression profile of ALR that is preferential for the larger isoform. This would also explain the oncogenic effect of ALR knock-out in mice (13). If the $15-\mathrm{kDa}$ isoform is associated with healthy hepatocytes while the longer isoform is upregulated in malignancy, a pan-ALR knock-out may be oncogenic. Further investigation dissecting the specific functions of the ALR isoforms in healthy cell and cancer biology is necessary.

ALR demonstrates potential as a therapeutic target in cancer treatment. Sufficient in vitro evidence suggests ALR silencing to be anti-tumoral. Silencing and/or inhibiting ALR in an HCC xenograft nude mouse model showed promising anti-tumor effect (19). However, considering oncogenic effect and increased hepatosteatosis in the murine liver-specific knock-out of ALR (13), further elucidation of the roles of the ALR isoforms must be performed. Perhaps specific targeting of the $21 / 23-\mathrm{kDa}$ isoform may minimize adverse outcome.
Overall, the currently available literature clearly suggests an oncogenic role of ALR in cancer biology. However, the complete function of ALR in cancer is not fully understood. Further investigations need to be performed on ALR function in tumor progression and as a targeted therapy. This early evidence, however, is promising for clinical use of this molecule.

\section{Conflicts of Interest}

None to declare.

\section{Acknowledgements}

The Authors received financial support from Kadner-Pitts Research Grant, Loyola Marymount University, Los Angeles, CA, USA.

\section{References}

1 Kirk GD, Bah E and Montesano R: Molecular epidemiology of human liver cancer: insights into etiology, pathogenesis and prevention from The Gambia, West Africa. Carcinogenesis 27(10): 2070-2082, 2006.

2 Bertuccio P, Turati F, Carioli G, Rodriguez T, La Vecchia C, Malvezzi $\mathrm{M}$ and Negri E: Global trends and predictions in hepatocellular carcinoma mortality. J Hepatol, 2017. doi: 10.1016/j.jhep.2017.03.011. [Epub ahead of print]

3 Torre LA, Siegel RL, Ward EM and Jemal A: Global cancer incidence and mortality rates and trends - an update. Cancer Epidem Biomar 25(1): 16-27, 2016.

4 Makarova-Rusher OV, Altekruse SF, McNeel TS, Ulahannan S, Duffy AG, Graubard BI, Greten TF and McGlynn KA: Population attributable fractions of risk factors for hepatocellular carcinoma in the United States. Cancer 122(11): 1757-1765, 2016.

5 Balogh T, Lőrincz T, Stiller I, Mandl J, Bánhegyi G and Szarka A: The Level of ALR is Regulated by the Quantity of Mitochondrial DNA. Pathol Oncol Res 22(2): 431-437, 2016.

6 Dabir DV, Hasson SA, Setoguchi K, Johnson ME, Wongkongkathep P, Douglas CJ, Zimmerman J, Damoiseaux R, Teitell MA and Koehler CM: A small molecule inhibitor of redox-regulated protein translocation into mitochondria. Dev Cell 25(1): 81-92, 2013.

7 Erdogan AJ and Riemer J: Mitochondrial disulfide relay and its substrates: mechanisms in health and disease. Cell Tissue Res 367(1): 59-72, 2017.

8 Jiang $\mathrm{X}$ and Wang X: Cytochrome C-mediated apoptosis. Annu Rev Biochem 73(1): 87-106, 2004.

9 Ibrahim S, Dayoub R, Melter M and Weiss TS: Activation of inflammation and cholestasis by Egr-1 is linked to liver regeneration by regulating ALR expression. Z Gastroenterol 54(12): A3-8, 2016.

10 Cao Y, Fu YL, Yu M, Yue PB, Ge CH, Xu WX, Zhan YQ, Li CY, Li W, Wang XH, Wang ZD, Li YH and Yang XM: Human augmenter of liver regeneration is important for hepatoma cell viability and resistance to radiation-induced oxidative stress. Free Radic Biol Med 47(7): 1057-1066, 2009.

11 Dayoub R, Wagner H, Bataille F, Stöltzing O, Spruss T, Buechler C, Schlitt HJ and Weiss TS: Liver regeneration associated protein (ALR) exhibits antimetastatic potential in hepatocellular carcinoma. Mol Med 17(3-4): 221-228, 2011. 
12 Denk GU, Wimmer R, Vennegeerts T, Pusl T, Thasler W and Rust C: Glycochenodeoxycholate-induced apoptosis is not reduced by augmenter of liver regeneration in the human hepatoma cell line HuH-7. Digestion 82(4): 262-264, 2010.

13 Gandhi CR, Chaillet JR, Nalesnik MA, Kumar S, Dangi A, Demetris AJ, Ferrell R, Wu T, Divanovic S, Stankeiwicz T, Shaffer B, Stolz DB, Harvey SA, Wang J and Starzl TE: Liverspecific deletion of augmenter of liver regeneration accelerates development of steatohepatitis and hepatocellular carcinoma in mice. Gastroenterology 148(2): 379-391, 2015.

14 Gatzidou E, Mantzourani M, Giaginis C, Giagini A, Patsouris E, Kouraklis G and Theocharis S: Augmenter of liver regeneration gene expression in human colon cancer cell lines and clinical tissue samples. J BUON 20(1): 84-91, 2015.

15 Ilowski M, Kleespies A, de Toni EN, Donabauer B, Jauch KW, Hengstler JG and Thasler WE: Augmenter of liver regeneration (ALR) protects human hepatocytes against apoptosis. Biochem Biophys Res Commun 404(1): 148-152, 2011.

16 Polimeno L, Pesetti B, Lisowsky T, Iannone F, Resta L, Giorgio F, Mallamaci R, Buttiglione M, Santovito D, Vitiello F, Mancini ME and Francavilla A: Protective effect of augmenter of liver regeneration on hydrogen peroxide-induced apoptosis in $\mathrm{SH}$ SY5Y human neuroblastoma cells. Free Radic Res 43(9): 865$875,2009$.

17 Polimeno L, Pesetti B, De Santis F, Resta L, Rossi R, De Palma A, Girardi B, Amoruso A and Francavilla A: Decreased expression of the augmenter of liver regeneration results in increased apoptosis and oxidative damage in human-derived glioma cells. Cell Death Dis 3: e289, 2012.
18 Shen Y, Liu Q, Sun H, Li X, Wang N and Guo H: Protective effect of augmenter of liver regeneration on vincristine-induced cell death in Jurkat $\mathrm{T}$ leukemia cells. Int Immunopharmacol 17(2): 162-167, 2013.

19 Tang L, Sun H, Zhang L, Deng JC, Guo H, Zhang L and Liu Q: Effects of the augmenter of liver regeneration on the biological behavior of hepatocellular carcinoma. Saudi Med J 30(8): 10011009, 2009.

20 Thasler WE, Schlott T, Thelen P, Hellerbrand C, Bataille F, Lichtenauer M, Schlitt HJ, Jauch KW and Weiss TS: Expression of augmenter of liver regeneration (ALR) in human liver cirrhosis and carcinoma. Histopathology 47(1): 57-66, 2005.

21 Yu HY, Xiang DR, Huang HJ, Li J and Sheng JF: Expression level of augmenter of liver regeneration in patients with hepatic failure and hepatocellular carcinoma. Hepatobiliary Pancreat Dis Int 9(5): 492-498, 2010.
Received May 9, 2017

Revised May 17, 2017

Accepted May 18, 2017 